passed for anyone to say what is the wattage that can be safely applied to the body, upon what authority does he rely? Then he goes on to assert that he would not like to be the "victim" of the experiment of having 400 watts applied to his body, while on his own showing he subjected his patients to 40,000 watts. Regarding the other points in Dr. Sloan's letter it is unnecessary for me to restate what $I$ have already explained. However, there is one point I wish to touch upon. He stated that $I$ answered one of the questions at the end of his paper. What I actually did was to deal, not with a question at the close, but with a query in the body of his paper. In the experiments he is carrying out to determine the difference in the physiological effects of currents by varying the frequencies he will no doubt see the necessity for definite data, and let me assure him he can claim no priority in the idea.

I shall be pleased to demonstrate to Dr. Sloan that five ampères at 100 volts can be passed through, or "in and out" of, the body, and I can promise him that the "victims" of the experiment will be none the worse. I can give him this assurance with the greatest confidence because $I$ have already done it with perfect safety. Further, I shall be pleased to place every means at his disposal to test the accuracy of the experiment and, if necessary, to supply him with the "victims." I have noted what Dr. Sloan has deemed to be the necessary qualification before one can become a member of bis scientific investigatory committee. Whether or not I possess this qualification it is not for me to say. The object of my criticism will have been served if attention has been directed to the danger of drawing hasty conclusions from bighfrequency currents experiments, based upon data which cannot bear the test of scientific investigation.

I am, Sirs, yours faithfully,

Cardiff, August 29th, 1907. J. CunNINGHAM Bowie.

\section{THE PRINCIPLES OF VACCINE-THERAPY.}

\section{To the Editors of THE LaNCET.}

SIRS,-I have read with great interest Sir A. E. Wright's lecture on this subject published in THE LANCET of August 17th and 24th. The illustration he gives of the value of a solution of sodium citrate 0.5 per cent. and sodium chloride 5 per cent. in dealing with certain localised morbid conditions seems to be capable of more general application. It has occurred to me that some trial of the method might be made in the case of septic infections of the uterus. The more or less complete and often long-continued cessation of the lochia in some of the more malignant forms of puerperal sepsis is well known. As the conditions in septic endometritis are to a greater or less degree-depending on the grade and mode of spread of the infectioncomparable to those obtaining in the instance cited, it seems reasonable to assume that a like beneficial effect might be expected in at least some cases. The procedure at any rate could do no harm. Probably where the spread of the infection is by way of the blood-vessels-as, unfortunately, is most frequent in the case of streptococcic endometritis-we ought not to look for so favourable a result. Where, however, dissemination follows the lymph-channels a blocking of these would lead to a lessened access of serum to the mucous surface and hence a deficiency of bacteriotropic substances in the endometrium and deeper-lying tissue. Without going into details it seems possible, e.g., by elevating the buttocks, to cause some of the solution to be retained in the uterus after donching in the ordinary way. The action of the two constituent salts would nere be precisely as in the case of a sinus.

I am, Sirs, yours faithfully,

London, S. W., August 26th, 1907.

A. G. BANKS,

\section{THE SEASONS AND MENTAL DIS- ORDERS.}

To the Editors of THE LANCET.

SIRS, -This question, the relations which the seasons bear to the incidence of mental disorders, one of considerable interest, was discussed in the medical journals some time ago. I regret that I am now unable to lay hands upon the particular journals in which the discussion took place, but its nature was such as to induce the desire to seek further definite facts for its elucidation. I proceeded, therefore, to analyse the admissions made into this house during the past 25 years, assigning to each the month on which the admission took place.

The results now before me show a not greatly divergent incidence in the various months. I need not give all the figures in detail ; it may suffice here to say that July stands some 25 per cent. above every other month, whilst the lowest figures are recorded at the beginning and end of the year, with some exceptions. The meaning of those figure is open to a variety of interpretation, and it would be of interest to ascertain how far they are borne out by the experience of other and larger communities. As far as my own statistics are concerned, one significant fact predominatesviz, that July, which is, or which ought to be, one of the hottest months of the year, has the highest average, whilst June comes within the next column of figures.

One may not unnaturally infer from this that the restlessness and sleeplessness often induced by high temperatures, to say nothing of the bodily exhaustion produced by extreme heat, are not without their influence as factors of the increase in question, and we have only to note the frequency of mental breakdown in tropical countries for confirmatory evidence.

I am, Sirs, yours faithfally,

West Malling, Kent, August 24th, 1907. JAMES ADAM.

\section{IMITATION NAUHEIM BATHS.}

To the Editors of THE LANCET.

SIRS,-So-called imitations of the Nauheim bath are now so generally employed that it may be worth while pointing out what a difference there is b stween the cutaneous reaction excited by the effervescing waters of Nauheim and that yielded by water through which carbonic acid gas is merely passed or in which it is generated.

At Nauheim, and to a less extent in baths in which the gas is generated by chemical interaction, the skin becomes covered with minute globules of the gas and on emerging therefrom the subject rivals in hue with the "cardinal of the seas." On this cutaneous reaction depends in part the influence of the Nauheim baths on the circulation, and as it is practically absent when compressed carbonic gas is merely passed through the water of the bath the value of this popular means of aëration must be very small. The difference is well exemplified in the ordinary gazogene. If the water be withdrawn soon after filling, or even within the first few hours after charging, it gives off but little gas and tastes "flat," showing that a certain lapse of time is necessary for the gas to become dissolved. Futher experiment will show that passing carbonic acid through water leaves the latter virtually unchanged. Whatever therapeutical value the Nauheim bath possesses in virtue of its gaseous constituent is due to the latter being in a state of aqueous solution, ready to be set free when the solution comes into contact with the skin.

While it may be conceded that the effects of the Nauheim treatment are only in a minor degree dependent on the action of the gas, this action is lacking when the gas is merely passed through the witer. To be operative the gas would require to be left in contact with the water in a cylinder under pressure for at least 12 hours before being employed.

Aix-les-Bains (Savoie) I am, Sirs, yours faithfully,

\section{BUTTERMILK IN ENTERIC DISEASE.}

\section{To the Editors of THE LANCET.}

SIRs,-- The difficulty often experienced by the practitioner in finding any food which can be retained by infants and young children suffering from acute or chronic febrile diarrboea with vomiting, especially in warm climates, induces me to bring to the notice of your readers a preparation which has a great reputation in the Argentine Republic in cases of this kind and which I cannot find mentioned in any of the books on "Diseases of Children" at my disposal. It might be found useful in the treatment of summer diarrhcea at home. It is sterilised buttermilk, sweetened, and is prepared as follows: Fresh buttermilk is slowly boiled in an earthenware vessel for half an hour-one litre (about 35 fluid ounces) will last for 24 hours - and while gently boiling from five to six dessertspoonfuls of powdered white sugar are added. It must be continually stirred with 
a wooden spoon and kept in a cool place in a jug with the lid off. One breakfast-cupful may be given every three hours warmed to $37^{\circ} \mathrm{C}$. $\left(99^{\circ} 7^{\circ} \mathrm{F}\right.$.) according to the age of the child.

The half-hour boiling includes the time the saucepan is on the fire, which should be a brisk one; the actual boiling is therefore about 20 minutes. Children will often digest and thrive on this food when on no other. At first they do not like it, as it tastes nasty, but this passes off after they have had to take it a few times. A change in the green slimy stools is noticed after a short time; they become of a natural yellow colour, the vomiting stops, the fever subsides, and the infant begins to pick up slowly. This food is much used by the Argentine and foreign doctors in the disease called in Spanish "Empacho," which is very prevalent and fatal among children under two years of age. It is also found. equally useful when the symptoms of gastro-enteritis are associated with dysentery.

I am, Sirs, yours faithfully,

K. BRuCE BARNETT, M.B., F.R. O.S. Trel.

Peking, North China, July 23rd, 1907.

Major, R.A.M.C.

\section{AN ASSOCIATION OF SHIPS' SURGEONS. To the Editors of THE LANCET.}

SIRS, - The suggestion contained in Mr. Metcalfe-Sharpe's letter to THE LANCET of August 24th re the formation of a Ships' Doctors' Association is one which I think merits the serious consideration of the profession. The benefits which such a society as that envisaged by Mr. Sharpe would confer upon the medical branch of the mercantile marine appear to be manifold. Those of our confrères who go down to the sea in ships have suffered much at the hands of the shipowner and his agents. Not the least important ducy falling to such a society as Mr. Sharpe purposes to form is to acquaint the medical officer himself of his status and prerogatives-in short, the idea should supply a long-felt want.

I am, Sirs, yours faithfully,

Matlock, August 26th, 1907. H. B. SYMONS.

\section{TOBACCO SMOKING AND PULMONARY TUBERCULOSIS. \\ To the Editors of THW LANOET.}

SIRs,-In your report of the discussion at the British Medical Association on tobacco smoking and phthisis you quote Dr. A. Newsholme as saying that my observations on the apparent immunity from phthisis of young persons under 22 years of age who were smokers as compared with nonsmokers of the same age were fallacious, inasmuch as the vast majority of those under 22 years did not smoke.

Most of us who have learnt anything of vital statistics have been readers of Dr. Newsholme's book, and I should be ashamed of being such a sorry student of his as to have made a statement based on such misleading grounds. The persons whom I had noticed in the out-patient departments of the Dablin hospitals as non-smokers and suffering from phthisis were of the age of from 16 to 22 years and males. Of this class-males from 16 to 22 years-I think that it is no exaggeration to state that the vast majority smoke. If a majority of the same age who are suffering from phthisis do not smoke there is, I submit, sufficient ground for investigation as to whetber tobacco smoke affects the incidence of phthisis.

To me it seems that no social habit of tuberculous patients is so remarkable as their general abstinence from tobacco. I do not imagine that a direct bactericidal effect can be the result of the inhalation of tobacco smoke, but it appears not unscientific to bold that the continued inhalation of the fumes into the respiratory tract may have such an effect on the membranes as to make it a less suitable soil for the bacillus tuberculosis.-I am, Sirs, yours faithfully, J. C. MCWALTER,

M.A. D.P.H., F.F.P.S. Glasg., M D. Brux.

Dublin, August 31st, $1907 . \quad$ Barrister-at-law.

\section{THE TRADE IN POISONS.}

To the Editors of THE LANCET.

SIRs,-In your issue of August 17th, p. 438, under the heading "Medicine and the Law," you observed, referring to the Brinkley case : "This points to $a$ dangerous state of affirs capable of existing in spite of the precautions prescribed by the law with a view to control the trade in poisons."

I have lately attended a case of narcotic poisoning, the patient being comatose for 48 hours. On searching I found a one-ounce bottle of chloroform (full) and a one-ounce bottle of laudanum (full), also a bottle of chlorodyne and a bottle which when full held $50 \quad 0.5$ gramme tablets of veronal but which now contained but one tablet. The first two bottles bore the label of a large London "Stores" and it is conceivable that the other two came from the same place; they were ordered by post and delivered in due course, and I was informed that the patient was in the habit of receiving in this way three one-ounce bottles of chloroform per month. If, as I suppose, for I am ignorant of the wording of the Act, it is sufficient to give one's name and address per post instead of signing the book, then I fail to see what is to prevent anyone from obtaining as much poison as he or she pleases.

August 27th, 1907

I am, Sirs, yours faithfully, M. B. Lond.

\section{THE TRIPPER'S LEAVINGS.}

To the Editors of THE LANCET.

SIRS,-In a recent issue of THE LANCET under this heading you called attention to the hideous carelessness of some. people in regard to the safety and comfort of others, instancing the habit displayed by certain trippers of leaving broken bottles in the grass near the site of an al fresco meal. Doubtless you had concrete examples in your mind, but here is another.

There is a golf course at Bexhill near the beach. On Saturday last I accompanied a small girl across some turf leading up to the golf club. I happened to be ahead and saw in the grass a smashed bottle exactly in the line where the child was just going to run. I was able to warn her She had sandals on, which would not have protected her ankles or the side of her feet at all, and these she had only put on a minute before. The beach here is pullulating with barefeet children, any of whom might have wandered there. Your protest is a valuable one.

Bexhill, August 29th, 1907

I am, Sirs, yours faithfully,

M.D.

\section{MANCHESTER.}

(FROM OUR OWN CORRESPONDENT.)

Port Sanitary Authority.

AT a meeting of the Manchester port sanitary anthority held the week before last Mr. W. F. Dearden reported that on June 12th a case of small-pox was found at a sailors lodging-house, and that the patient had arrived by a vessel reaching the docks on the $6 \mathrm{th}$. There were 15 persons on board, and of these three showed good vaccination and revaccination marks; the remaining 12 were revaccinated at once. The men were kept under observation, but there had been no spread of the disease. This incident shows the need for careful watchfulness and for all possible precautions against the introduction of infectious diseases, more especially of small-pox, the defences against it, in the present state of the vaccination question, being by no means as strong as they should be. Mr. Dearden also reported the existence of friction in connexion with the removal of condemned carcasses from the foreign animals wharf. It seems that the inspector of the Board of Agriculture first of all allowed the authority's steam launch to come alongside the wharf to take aboard the condemned meat, but later objected to this being done, referring the medical officer to the section of the Foreign Animals Order, 1903, governing the matter. Mr. Dearden did not think the regulation applicable to the using of the landing place as had been done. If condemned meat could be removed by the port authority it was difficult to understand why it could not be removed by water. It is unfortunate that anything should be allowed to interfere with the speedy and convenient removal of condemned meat. It was decided by the port authority to refer the matter to the Board of Agriculture for its ruling.-At a meeting of the authority held yesterday it was reported that during the past month two cases of enteric fever had occurred among seamen entering the port. The disease was supposed to have been contracted 